\title{
Columnar ossicles of Permian crinoids, including two new genera, from the Grupera Formation (Asselian-Sakmarian) of Chiapas, Mexico
}

\author{
Osículos columnares de crinoideos pérmicos, incluidos dos géneros nuevos, de la Formación Grupera \\ (Asseliano-Sakmariano) de Chiapas, México
}

Miguel A. Torres-Martínez ${ }^{1, *}$, Rafael Villanueva-Olea ${ }^{2}$, Francisco Sour-Tovar $^{3}$

Departamento de Paleontología, Instituto de Geología. Universidad Nacional Autónoma de México, Circuito de la Investigación Científica, Avenida Universidad 3000, Coyoacán, 04510, Mexico City, Mexico.

${ }^{2}$ Departamento de Biología Evolutiva, Facultad de Ciencias. Universidad Nacional Autónoma de México, Circuito Interior, Avenida Universidad 3000, Coyoacán, 04510, Mexico City, Mexico.

${ }^{3}$ Museo de Paleontología, Facultad de Ciencias. Universidad Nacional Autónoma de México, Circuito Interior, Avenida Universidad 3000, Coyoacán, 04510, Mexico City, Mexico.

* Corresponding author: (M.A. Torres-Martínez) miguelatm@geologia.unam.mx

\begin{abstract}
How to cite this article:
Torres-Martínez, M. A., Villanueva-Olea R., Sour-Tovar, F., 2020, Columnar ossicles of Permian crinoids, including two new genera, from the Grupera Formation (AsselianSakmarian) of Chiapas, Mexico: Boletín de la Sociedad Geológica Mexicana, 72 (2), A280819. http://dx.doi.org/10.18268/ BSGM2020v72n2a280819
\end{abstract}

Manuscript received: June 27, 2019

Corrected manuscript received: October 15, 2019 Manuscript accepted: October 29, 2019

Peer Reviewing under the responsibility of Universidad Nacional Autónoma de México.

\section{ABSTRACT}

Eleven morphotypes of columnar ossicles of Permian crinoids collected from the Grupera Formation (Asselian-Sakmarian) are described. Floricyclocion heteromorpha and Cyclogrupera minor are proposed as new morphogenera and morphospecies. Preserved elements allow relating the depositional paleoenvironment to restricted waters of the inner ramp. The stratigraphical range of Cyclocaudiculus regularis, Heterostelechus keithi, Lamprosterigma erathense and Cyclocaudex insaturatus is extended from the Pennsylvanian (Upper Carboniferous) to the lower Cisuralian (lower Permian). The record of all parataxa studied is the first in Chiapas, Mexico, and the first formal work on Permian crinoids from the Chicomuselo region. Because the specimens were found in a Permian unit that had been related to the Grandian Province of North America (Texas and New Mexico in USA; Coahuila, Sonora and Chiapas in Mexico; and Palmarito in Venezuela), it is suggested that crinoids should be part of the same paleoprovince.

Keywords: Parataxa, Floricyclocion, Cyclogrupera, AsselianSakmarian, Grandian Province.

\section{RESUMEN}

Se describen 11 morfotipos de osículos columnares de crinoideos pérmicos de la Formación Grupera (Asseliano-Sakmariano). Floricyclocion heteromorpha y Cyclogrupera minor se proponen como nuevos morfogéneros y morfoespecies. Los elementos conservados permitieron relacionar el paloambiente de depósito con aguas restringidas de la rampa interna. El alcance estratigráfico de Cyclocaudiculus regularis, Heterostelechus keithi, Lamprosterigma erathense y Cyclocaudex insaturatus se extiende del Pensilvánico (Carbonifero Superior) al Cisuraliano inferior (Pérmico inferior). Todos los parataxones se registran por primera vez para Chiapas, México, además de que éste es el primer trabajo formal sobre crinoideos pérmicos de la región de Chicomuselo. Debido a que los ejemplares fueron encontrados en una unidad pérmica que ha sido relacionada con la Provincia Grandiana de Norteamérica (Texas y Nuevo México en EUA; Coahuila, Sonora y Chiapas en México; y Palmarito en Venezuela), se sugiere que los crinoideos formarian parte de esta misma paleoprovincia.

Palabras clave: Parataxones, Floricyclocion, Cyclogrupera, Asseliano-Sakmariano, Provincia Grandiana. 


\section{Introduction}

Crinoids have been considered one of the most important group of invertebrates of shallow marine environments, especially during the Paleozoic. Although the fossil record of crinoids is common and diverse in Phanerozoic rocks, the abundance of disarticulated ossicles that make up their skeletons is greater than the reports of articulated specimens. In particular, assemblages of articulated crinoids are exceptional, and they are typically confined to particular bedding planes or localized lenses (Hess et al., 2002). The scarcity of complete specimens is the result of the way in which the peduncle, calyx and crown that compose the body are articulated. These parts are composed of a series of plates or ossicles of calcitic-magnesian composition adjoined by means of ligamentary connective tissue, either rigid or flexible. Upon death these connective tissues quickly decay, and the great majority of fossil crinoidal remains are disarticulated by various processes (Hess et al., 2002). This causes the post-mortem disjoining of crinoids to occur quickly, resulting in the common finding of isolated ossicles. This process makes it difficult to accurately identify these elements to low taxonomic levels whereby they are essentially ignored (Thomka et al., 2012; Donovan and Doyle, 2019).

Considering this problem, several researchers (e.g., Moore and Jeffords, 1968; Fearnhead and Donovan, 2015; Donovan and Doyle, 2019) have proposed a classification system based on the morphology of the ossicles, working mainly on Paleozoic records. Such a scheme is based on the temporal and spatial distribution of each morph, suggesting the possibility that these fossils could be biostratigraphic or paleobiogeographic useful. In this context, all works about isolated or disarticulated ossicles are essential tasks in crinoid paleontology (Hess et al., 2002), because the value of such incomplete material has been recognized as an important, but neglected, area of research (Thomka et al., 2012). According to the classification of Moore and Jeffords (1968) and given that there are no previous studies on Permian crinoids from Chiapas, this paper aims to describe a series of columnar ossicles from the Grupera Formation, a unit of early Cisuralian age (Asselian-Sakmarian). This information expands the current data on the distribution of isolated elements of Paleozoic crinoids. A second aim is to discuss the possible biostratigraphic and paleogeographic implications of the material studied in the Permian of Chiapas.

\section{Geological setting}

The locality, where the material studied was sampled, is about $15^{\circ} 43^{\prime} 14.2^{\prime \prime} \mathrm{N}-92^{\circ} 26^{\prime} 46^{\prime \prime} \mathrm{W}$, in the Chicomuselo municipality, Chiapas, Mexico (Figure 1). The specimens were deposited in calcareous sandstones of fine grain in the Grupera Formation, considered the oldest Permian lithostratigraphic unit from the Chicomuselo region. This formation is well-exposed in southeastern Chiapas extending from Loma Alta and La Pinta to the Guatemala frontier (Gutiérrez-Gil, 1956).

The Paleozoic succession begins with the Santa Rosa Formation (Upper Mississippian-Middle Pennsylvanian). This unit is mainly composed of shale, phyllite and slate (Gutiérrez-Gil, 1956). Overlaying the Santa Rosa Formation is the Grupera Formation from the Asselian-Sakmarian (Cisuralian), age assigned by Thompson and Miller (1944) by means of the foraminifera Schwagerina gruperaensis and Schwagerina chiapasensis. Its base is made up of $300 \mathrm{~m}$ of silicified shale intercalated with dark gray limestone; above, there are $117 \mathrm{~m}$ of gray shale and sandstone strata, followed by $110 \mathrm{~m}$ of alternations of dark gray limestone and shale (Gutiérrez-Gil, 1956). The succession continues with La Vainilla Limestone, composed of limestone and argillaceous limestone.

This unit apparently overlays the Grupera Formation; however, its actual stratigraphic position remains unclear and has been suggested that the La Vainilla Limestone could be the base of the Paso Hondo Formation (Gutiérrez-Gil, 1956; López-Ramos, 1979). The Paleozoic succession 
ends with the Paso Hondo Formation (upper Cisuralian-lower Guadalupian) mainly composed of $600 \mathrm{~m}$ of light to dark gray limestones of Artinskian-Roadian age (Gutiérrez-Gil, 1956; Hernández-García, 1973; Torres-Martínez et al., 2019) (Figure 2).

\section{Systematic paleontology}

The material described is deposited at Museo de Paleontología of the Facultad de Ciencias, Universidad Nacional Autónoma de México. Figured and type specimens are designated in the descriptions by the prefix FCMP. The specimens are preserved in calcareous sandstone as authigenic molds. In all cases rubber casts were made.

Class Crinoidea Miller, 1821

Subclass and Order Uncertain Moore and
Jeffords, 1968

[Group Pentameri] Moore and Jeffords, 1968 Family Pentacauliscidae Moore and Jeffords, 1968 Genus Pentagonopternix Moore and Jeffords, 1968

Type species. Pentagonopternix insculptus Moore and Jeffords, 1968.

Diagnosis. Heteromorphic and transversely pentastellate stem; nodals with 5 elliptical cirrus scars; internodals with 14 columnals, alternating in size; sutures indented forming pits wider than high with no development of radial pores; articular facets having a star-shaped belt of medium-length straight crenulae, their outer ends aligned in inwardly bent curve, the inner ends abutting stellate areola with a slightly concave floor; lumen moderately large and circular.

Pentagonopternix? sp.

Figure $3 \mathrm{~A}$ and $3 \mathrm{~B}$

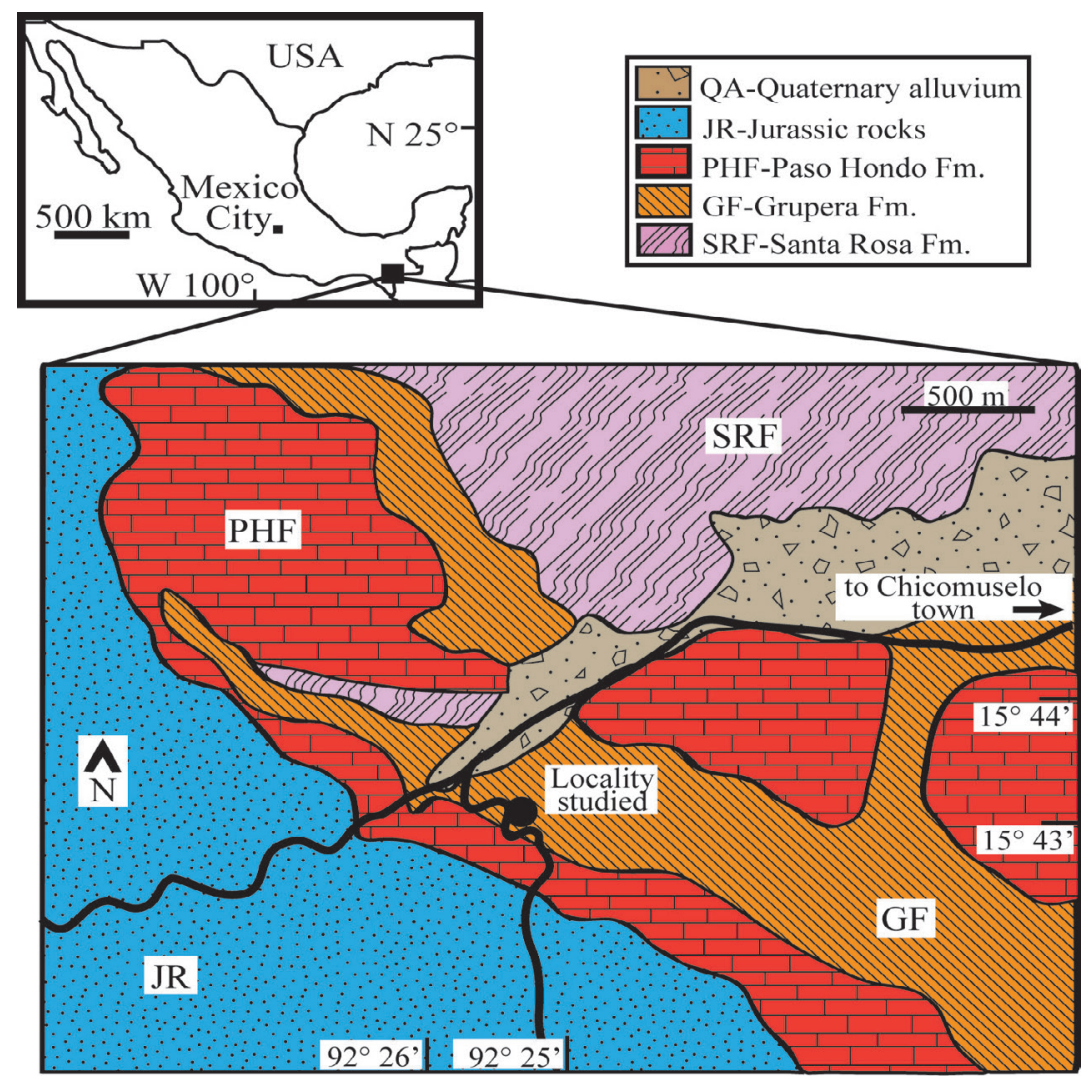

Figure 1 Geological position of the locality, where crinoids occur, in the Grupera Formation. Map modified from Jiménez-Hernández et al. (2005). 


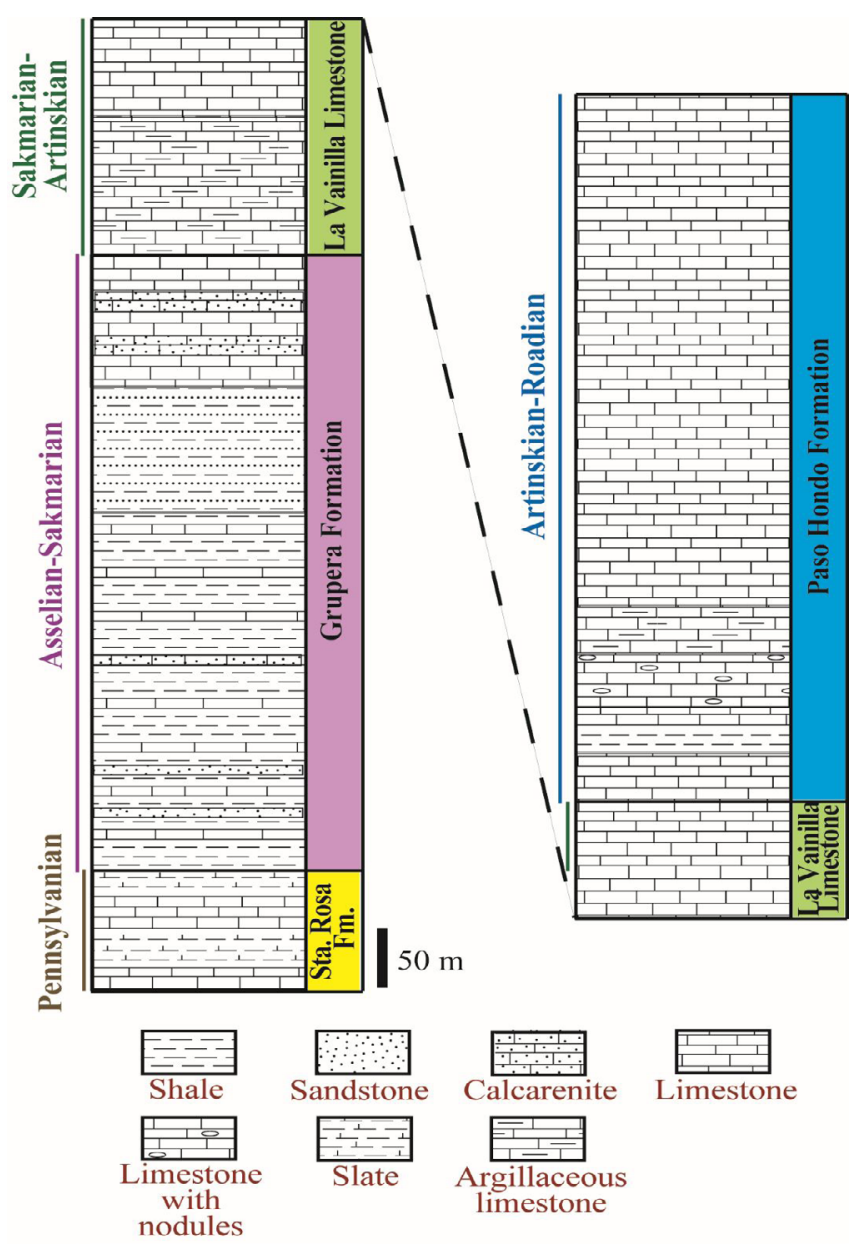

Paleozoic stratigraphy of the Chicomuselo region.

Description. Columnals with a pentastellate shape; crenularium poorly preserved; small, subpentagonal lumen.

Material. FGMP 1349, 1350.

Occurrence. Fine-grained calcareous sandstones, Grupera Formation (Asselian-Sakmarian), Chiapas, Mexico.

Remarks. The specimens are questionably assigned to the morphogenus Pentagonopternix mainly due to the stellate shape of the ossicle. The poor conservation of several features of the articular facet, as well as the lack of a noditaxis,does not allow making a reliable assignment.

This morphogenus has been found in the Chaffin Limestone from Gzhelian (Upper Pennsylvanian) age of Texas (Moore and Jeffords, 1968), in the Antiinskiy Horizon from the middle Permian (Roadian-Wordian) of the Transbaikal region of Russia (Kotlyar et al., 2006), and in the Imtachan Formation from the upper Permian (Lopingian) of Verkhoyansk, Russia (Biakov et al., 2016). In Mexico, it had only been recorded in the Middle Pennsylvanian of Sierra Agua Verde, Sonora (Buitrón-Sánchez et al., 2015).

[Group Cyclici] Moore and Jeffords, 1968 Family Cyclomischidae Moore and Jeffords, 1968 Genus Cyclogrupera n. gen.

Type species. Cyclogrupera minor n. sp.

Etymology. Refers to the circular shape of the articular facet, as well as to the lithostratigraphic unit where the specimens were collected.

Diagnosis. Homeomorphic stem of small diameter, gently rounded in longitudinal profile; granulose walls; articular facet circular; crenularium 
large, reaching the outline of perilumen; crenulae coarse, with crenellae and culmina of the same size; without areola; perilumen gently marked, delineating the lumen outline; lumen small, circular.

\section{Cyclogrupera minor $\mathrm{n}$. sp.}

Figure $3 \mathrm{C}$ and $3 \mathrm{D}$

Etymology. Refers to the tiny size of the specimens.

Diagnosis. As the genus.

Description. With traits of the genus; besides this displays 13 crenulae, lumen $0.5 \mathrm{~mm}$ diameter and crenularium $0.7 \mathrm{~mm}$ width.

Material. FGMP 1351.

Occurrence. Fine-grained calcareous sandstones, Grupera Formation (Asselian-Sakmarian), Chiapas, Mexico.

Remarks. The Chiapas material was assigned to the family Leptocarphiidae due to the slender stem, broad crenularium and presence of a perilumen surrounding the circular lumen. Cyclocaudiculus differs from Cyclogrupera by the lack of areola; Nothrosterigma differs by its coarser, convex and ring-shaped perilumen surrounding the lumen, and Heterostelechus displays an elevated perilumen from the surface of the articular facet.

\section{Genus Cyclocaudex Moore and Jeffords, 1968}

Type species. Cyclocaudex typicus Moore and Jeffords, 1968.

Diagnosis. Stem heteromorphic; straight-sided to gently convex longitudinal profile; nodals bearing cirrus scars, not wider than internodals and slightly taller; crenularium wide with long and straight crenulae; areola small, lacking or becoming a perilumen; lumen small to medium in size, and circular, subpentagonal or quinquelobate in outline.

Cyclocaudex typicus Moore and Jeffords, 1968

Figure $3 \mathrm{E}$ to $3 \mathrm{~N}$
Description. Column with straight to slightly rounded longitudinal profile, with granulose walls; heteromorphic stem; sutures gently crenulate; articular facet subcircular; crenularium broad, with slender crenulae, many bifurcated; areola is not conspicuous, reduced in size, granulose and flat, which surrounds a large, circular lumen; inside of the lumen, a circular and minute jugula is observed.

Material. FCMP 1352-1357.

Occurrence. Fine-grained calcareous sandstones, Grupera Formation (Asselian-Sakmarian), Chiapas, Mexico.

Remarks. The specimens of the Grupera Formation resemble Lomalegnum hormidium. However, C. typicus has neither the sutures strongly crenulate nor the peripheral ends of culmina typical of Lomalegnum.

The material can also be distinguished from Cyclocaudex jucundus by the lack of a broad areola with a depressed surface. Cyclocaudex typicus has been reported in the Upper Pennsylvanian of Texas in the United States (Moore and Jeffords, 1968), as well as in the Carboniferous of Oaxaca (Villanueva-Olea et al., 2011), Upper Pennsylvanian of Puebla (Esquivel-Macías, 1996) and middle Permian of Oaxaca in Mexico (Vachard et al., 1997). This is the first record of the taxon in the lower Permian of North America.

$$
\begin{gathered}
\text { Cyclocaudex plenus Moore and Jeffords, } 1968 \\
\text { Figure } 3 \mathrm{O} \text { to 3S }
\end{gathered}
$$

Description. Ossicles of circular shape in outline; conspicuous cirrus, which endow a greater size to the nodals; sutures slightly crenulate; ossicles of at least three different heights, which suggests a minimum noditaxis of four columnals; crenularium very wide with narrow crenulae; culmina wider than crenellae, bifurcating near margins; areola narrow and flat; lumen of reduced size, irregular to circular in outline.

Material. FCMP 1358-1360. 
Occurrence. Fine-grained calcareous sandstones, Grupera Formation (Asselian-Sakmarian), Chiapas, Mexico.

Remarks. The material of Chiapas is distinguished from Mooreanteris waylandensis from the Graham Formation of Texas (Moore and Jeffords, 1968) by its symmetric articular facet and suture strongly crenulate. Cyclocaudex plenus is dissimilar to Cyclocaudex typicus from the Thrifty Formation of the Upper Pennsylvanian of Texas (Moore and Jeffords, 1968) by its poorly defined boundary between the reduced areola and the crenularium, and the crenulae bifurcated near the edge of the areola. Cyclocaudex plenus has been reported in the Upper Pennsylvanian of Texas (Moore and Jeffords, 1968) and in the lower Permian of Calnali (Moreno and Patiño 1981) and Pemuxco, Hidalgo (Arellano et al., 1998; Buitrón-Sánchez et al., 2017).

\section{Cyclocaudex jucundus Moore and Jeffords, 1968} Figure $3 \mathrm{~T}$ and $3 \mathrm{U}$

Description. Latus of columnals slightly rounded and convex; columnals with slight differences in height; sutures crenulate; articular facet circular; crenularium of medium size, with some bifurcations at the outer half; crenulae narrow with culmina wider than crenellae; lumen large and circular; areola broad, depressed, which deepens towards the interior of the lumen.

Material. FGMP 1361.

Occurrence. Fine-grained calcareous sandstones, Grupera Formation (Asselian-Sakmarian), Chiapas, Mexico.

Remarks. Cyclocaudex jucundus occurs in the Upper Pennsylvanian of Texas (Moore and Jeffords, 1968), in addition to the Pennsylvanian of Calnali, Hidalgo (Buitrón et al., 1987), the Upper Pennsylvanian (Velasco de León and Buitrón, 1992) and Permian (Esquivel et al., 2000) of San Salvador Patlanoaya, Puebla, the lower Permian of Pemuxco, Hidalgo (Arellano et al., 1998), MiddleUpper Pennsylvanian of Sonora (Buitrón-Sánchez et al., 2012; Villanueva-Olea et al., 2016) and in the middle Permian of Sonora (Buitrón et al., 2007a).
Cyclocaudex insaturatus Moore and Jeffords, 1968

Figure 3V

Description. Articular facet circular; crenularium very wide, reaching the rim of the lumen; crenulae very narrow, with culmina wider than crenellae, some bifurcating in the medium part; lumen of medium size and circular.

Material. FCMP 1362.

Occurrence. Fine-grained calcareous sandstones, Grupera Formation (Asselian-Sakmarian), Chiapas, Mexico.

Remarks. The specimen of Chiapas differs from Cyclocaudex plenus by its larger lumen and crenulae reaching the rim of the lumen. Cyclocaudex insaturatus is dissimilar to Cyclocaudex aptus from the Lower Mississippian of Kentucky (Moore and Jeffords, 1968) by its coarser and less abundant crenulae and a larger lumen. The species differs from Cyclocaudex congregalis of the Lower Mississippian of Kentucky (Moore and Jeffords, 1968) by its flat crenularium, without inner rounded edges. Cyclocaudex insaturatus occurs in the Middle Pennsylvanian of Kansas (Moore and Jeffords, 1968), as well as in the Pennsylvanian of Calnali, Hidalgo (Buitrón-Sánchez et al., 1987) and the Middle Mississippian and Lower-Middle Pennsylvanian of Santiago Ixtaltepec, Oaxaca (Villanueva-Olea et al., 2011). This is the first record of C. insaturatus from the Permian.

\section{Family Floricyclidae Moore and Jeffords, 1968 Genus Floricyclocion n. gen.}

Type species. Floricyclocion heteromorpha n. sp. Etymology. Refers to the floriform lumen.

Diagnosis. Floricyclidae characterized by a straight and heteromorphic stem columnals with median length crenulae, flat areola and medium sized stellate lumen.

\section{Floricyclocion heteromorpha $\mathrm{n}$. sp.}

Figure $4 \mathrm{~A}$ and $4 \mathrm{~B}$

Etymology. Refers to the heteromorph stem. 
Diagnosis. As the genus.

Description. Column straight in lateral view, heteromorphic, with columnals of different length; articular facet circular; crenularium of medium size, with straight and coarse crenulae; culmina slightly coarser than crenellae; areola flat and granulose; lumen medium sized and stellate.

Material. FGMP 1363.

Occurrence. Fine-grained calcareous sandstones, Grupera Formation (Asselian-Sakmarian), Chiapas, Mexico.

Remarks. The morphogenus Cyclocion is distinguished from Floricyclocion by its very short crenulae and larger lumen; sutures strongly crenulate and nodals strongly keeled. On the other hand, the genus Lamprosterigma displays a depression in the areola, in addition to very slender and numerous crenulae. Likewise, the Floricyclus differs from the new morphogenus by its very marked and granulose perilumen, with division of some crenulae. Floricyclocion is assigned to the family Floricyclidae by its floriform lumen and the presence of a straight longitudinal profile of the stem.

\section{Genus Lamprosterigma Moore and Jeffords, 1968}

Type species. Lamprosterigma mirificum Moore and Jeffords, 1968.

Diagnosis. Homeomorphic stem; low-height columnals; longitudinal profile straight or a little convex; sutures noncrenulate, not indented; articular facet with moderately broad crenularium; crenulae straight, set off from the areola by a sharp edge; areola bowl-shaped with smooth surface, extending to the edge of the pentalobate broad lumen, or separated from it by a narrow perilumen.

Lamprosterigma erathense Moore and Jeffords, 1968 Figure 4C

Description. Articular facet circular; crenularium wide with slender crenulae, some bifurcating close to the periphery; culmina wider than crenellae; areola granulose, set off from the crenularium by a depression and grades into a discrete perilumen; lumen wide, floriform, with poorly developed petals.

Material. FCMP 1364.

Occurrence. Fine-grained calcareous sandstones, Grupera Formation (Asselian-Sakmarian), Chiapas, Mexico.

Remarks. The specimen was compared with Lamprosterigma mirificum (Middle Pennsylvanian) of Kansas (Moore and Jeffords, 1968) however $L$. mirificum does not display a developed perilumen. Plummeranteris from the Pennsylvanian of Texas (Moore and Jeffords, 1968) is dissimilar to the morphogenus Lamprosterigma by its coarse and straight crenulae, and strongly floriform perilumen, with well-developed petals. Lamprosterigma erathense is reported from the Middle Pennsylvanian of Texas (Moore and Jeffords, 1968) and the Middle Pennsylvanian (Atokan) of Sonora (Buitrón-Sánchez et al., 2007b). This is the first occurrence of $L$. erathense in Permian rocks.

Family Leptocarphiidae Moore and Jeffords, 1968 Genus Preptopremnum Moore and Jeffords, 1968

Type species. Preptopremnum rugosum Moore and Jeffords, 1968

Diagnosis. Medium-sized column; articular facets slightly narrower than the largest column width; rounded longitudinal profile; crenularium narrow; medium to coarse crenulae set off from a broad and flat areola, slightly concave or convex, with marks of vermiculate or granulose irregularities; large and circular lumen, bordered by a narrow perilumen or an accentuated edge of the areola; lumen with claustra at mid-height of columnal plates, jugulum and jugular ramparts in the center of claustra.

\section{Preptopremnum cf. laeve Moore and Jeffords, 1968} Figure $4 \mathrm{D}$ to $4 \mathrm{H}$

Description. Column with a slightly rounded longitudinal profile; articular facet circular with a very slender crenularium and coarse crenulae; culmina wider than crenellae; areola wide and granulose 


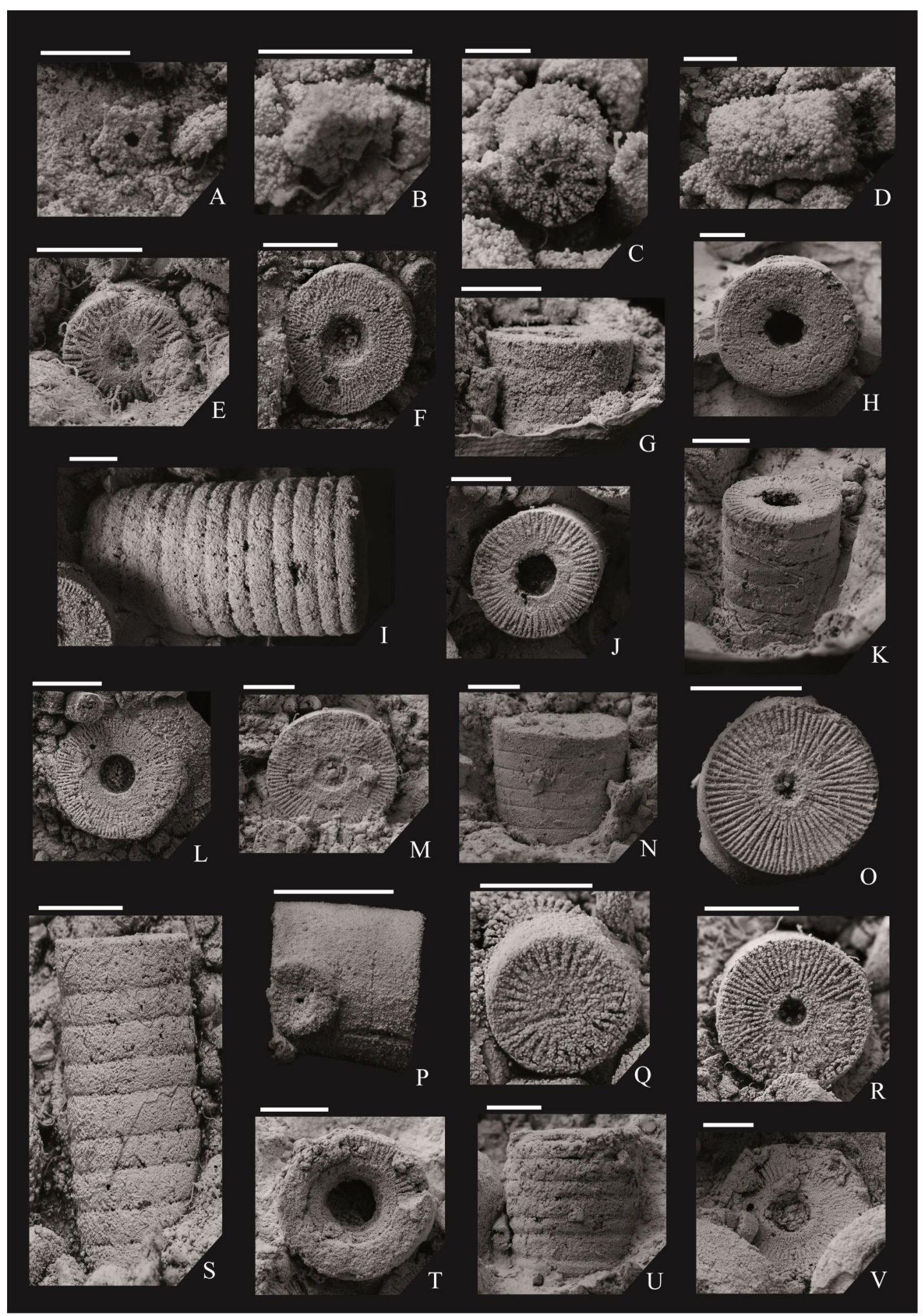

Figure 3 (A, B) Pentagonopternix? sp., samples A) FCMP 1350; B) FCMP 1349. (C, D) Cyclogrupera minor n. gen and n. sp., sample FCMP 1351. (E-N) Cyclocaudex typicus, samples E) FCMP 1354; F, G) FCMP 1357; H, I) FCMP 1352; J, K) FCMP 1355; L) FCMP 1356; M, N) FCMP 1353. (O-S) Cyclocaudex plenus, samples O, P) FCMP 1359; Q) FCMP 1360; R, S) FCMP 1358. (T, U) Cyclocaudex jucundus, sample FCMP 1361. (V) Cyclocaudex insaturatus, sample FCMP 1362. All specimens illustrated are rubber casts. Scale bars $=5 \mathrm{~mm}$, except $\mathrm{A}, \mathrm{B}, \mathrm{L}=2$ $\mathrm{mm} ; \mathrm{C}, \mathrm{D}=1 \mathrm{~mm}$. 
in the area surrounding lumen, slightly elevated, resembling a broad perilumen; lumen circular.

Material. FCMP 1365-1368.

Occurrence. Fine-grained calcareous sandstones, Grupera Formation (Asselian-Sakmarian), Chiapas, Mexico.

Remarks. Preptopremnum rugosum is distinguished from $P$. laeve by the longer crenulae, a granulose and rounded medium-sized areola, and a circular large lumen. Nevertheless, the Chiapas specimens are slightly different to those described by Moore and Jeffords (1968) because of the occurrence of great quantity of granules on the latus of the columnals. Preptopremnum laeve occurs in the Middle Pennsylvanian of Texas in the United States (Moore and Jeffords, 1968), as well as in the Pennsylvanian of Sonora (Buitrón-Sánchez et al., 2005, 2007b, 2012; 2015) and in the Middle Pennsylvanian-lower Permian of Sierra Las Pintas, Baja California, Mexico (Navas-Parejo et al., 2018).

\section{Genus Heterostelechus Moore and Jeffords, 1968}

Diagnosis. Stem heteromorphic; columnals rounded in longitudinal profile; indented and crenulate sutures; one or more cirrus scars in nodals, which are taller than internodals, but not much wider; coarse straight crenulae of medium length; areola concave, elevated tract around circular lumen, also classifiable as a perilumen.

Heterostelechus jeffordsi Miller, 1968 (in Moore and Jeffords, 1968)

Figure $4 \mathrm{I}$ to $4 \mathrm{~N}$

Description. Column with a straight profile; noditaxis of three different sizes in the height of columnals (nodals and internodals IIN and 2IN); sutures crenulate; articular facet circular; medium-sized crenularium with coarse crenulae; culmina and crenella of the same size; areola elevated and granulose; medium-sized subpentagonal lumen.

Material. FCMP 1369-1373.

Occurrence. Fine-grained calcareous sandstones,
Grupera Formation (Asselian-Sakmarian), Chiapas, Mexico.

Remarks. The material of Chiapas was assigned to the morphospecies by the articular facet features. Heterostelechus jeffordsi is distinguished from the rest of the morphospecies mainly by its column profile slightly rounded. This taxon has been recorded in the Late Pennsylvanian of Texas (Moore and Jeffords, 1968) and Guerrero, Mexico (Flores de Dios and Buitrón-Sánchez, 1982; Esquivel-Macías et al., 2004). This is the first report of the morphospecies in the early Permian.

Heterostelechus cf. keithi Miller, 1968 (in Moore and Jeffords, 1968)

Figure $4 \mathrm{O}$ and $4 \mathrm{P}$

Description. Plate with a smooth and straight latus; articular facet circular; crenularium of medium size; coarse and straight crenulae, with crenellae and culmina of the same width; areola slightly concave, forming a pentagonal outline in the inner edge of the crenularium; lumen small and circular.

Material. FCMP 1374, 1375.

Occurrence. Fine-grained calcareous sandstones, Grupera Formation (Asselian-Sakmarian), Chiapas, Mexico.

Remarks. The material resembles Heterostelechus keithi but its straight longitudinal profile and smaller lumen does not allow making a reliable assignment. Heterostelechus keithi has been recorded in the Pennsylvanian of Texas (Moore and Jeffords, 1968), in addition to Hidalgo (Buitrón-Sánchez et al., 1987), Puebla (Velasco de León and Buitrón-Sánchez, 1992) and Sonora in Mexico (Buitrón-Sánchez et al., 2007b, 2008, 2015). This is the first report in the Permian of North America.

Genus Cyclocaudiculus Moore and Jeffords, 1968

Type species. Cyclocaudiculus regularis Moore and Jeffords, 1968.

Diagnosis. Stem with a straight longitudinal profile; nodals bearing one single scar; crenularium 
with coarse and straight crenulae; lumen circular, small or medium.

\section{Cyclocaudiculus regularis Moore and Jeffords, 1968} Figure 4Q to $4 \mathrm{~V}$

Description. Stem heteromorphic, straight in longitudinal profile; articular facet circular which occupies the width of the columnal; crenularium with coarse crenulae; culmina wider than crenellae; areola flat with perilumen; crenularium small and subcircular.

Material. FGMP 1376-1379.

Occurrence. Fine-grained calcareous sandstones, Grupera Formation (Asselian-Sakmarian), Chiapas, Mexico.

Remarks. Cyclocaudiculus regularis is reported in the Gzhelian (Upper Pennsylvanian) of Texas in the United States (Moore and Jeffords, 1968) and in the Pennsylvanian of Sierra Las Mesteñas, Sonora, Mexico (Villanueva-Olea et al., 2016). This is the first record of the taxon in the lower Permian.

\section{Discussion}

\subsection{DEPOSITIONAL PALEOENVIRONMENT}

The study of Paleozoic environments of the Chicomuselo region has been, in general, very scarce, especially for the Grupera Formation. Previously, only the study of one carbonate succession from the Paso Hondo Formation (Artinskian-Roadian) was included in which the features of a carbonated homoclinal ramp were described (Torres-Martínez et al., 2017). Nonetheless, the Grupera Formation underlays the Paso Hondo Formation, having clear lithological differences. The only previous interpretation of an environment of the Grupera Formation is that done by Hernández-García (1973), who described the paleoenvironment of the Grupera unit as shallow waters of low energy, well-illuminated and oxygenated, protected from the waves. This interpretation is extremely shallow because the author focused on a group of sedimentary features without considering the lithological changes through the unit.

In this context, the parataxa studied are embedded in calcareous sandstone of fine grain, which is characterized by clay-rich matrix and calcareous cement. The skeletal grains are mainly represented by abundant ossicles and pleuricolumnals articulated of crinoids whereas phylloid algae and benthic foraminifera of the genera Geinitzina and Nodosinelloides are rare. Scattered microbial components are observed. Euhedral dolomite crystals and pyrite as well as iron oxides are dispersed in the fine-grained matrix.

The presence of benthic foraminifera and phylloid algae suggests nearness with open waters; on the contrary, the occurrence of microbial growth, clay and sands indicates a proximity with the intertidal zone. The abundance of crinoids suggests high productivity in the euphotic zone, relating the environment to restricted waters of the inner ramp. Although crinoid ossicles studied are mostly disarticulated, the poor sorting of crinoid fragments associated with well-preserved crinoid pleuricolumnals indicates burial in quiet-water settings without longer transport (Flügel, 2010). Nonetheless, there is a chance that the association was produced by possible scavenging dispersion of crinoid remains.

\subsection{PALEOBIOGEOGRAPHY AND IMPLICATIONS IN AGE}

In previous studies (Müllerried et al., 1941; Thompson and Miller, 1944; Torres-Martínez et al., 2016, 2019), it has been pointed out that the early-middle Permian faunas of southern Chiapas have a great resemblance with those described in different localities from Texas and New Mexico. The similarity of faunas has established that, during this period, there was a marine connection through an epicontinental sea which linked the south-central United States and the south of Mexico (Torres-Martínez et al., 2016). This connection occurred in the Grandian Province, characterized by numerous taxa of fusulinids, cephalopods and brachiopods of tropical and subtropical environments (Yancey, 1975; Shen and Shi, 2004; Shen et al., 2013). 

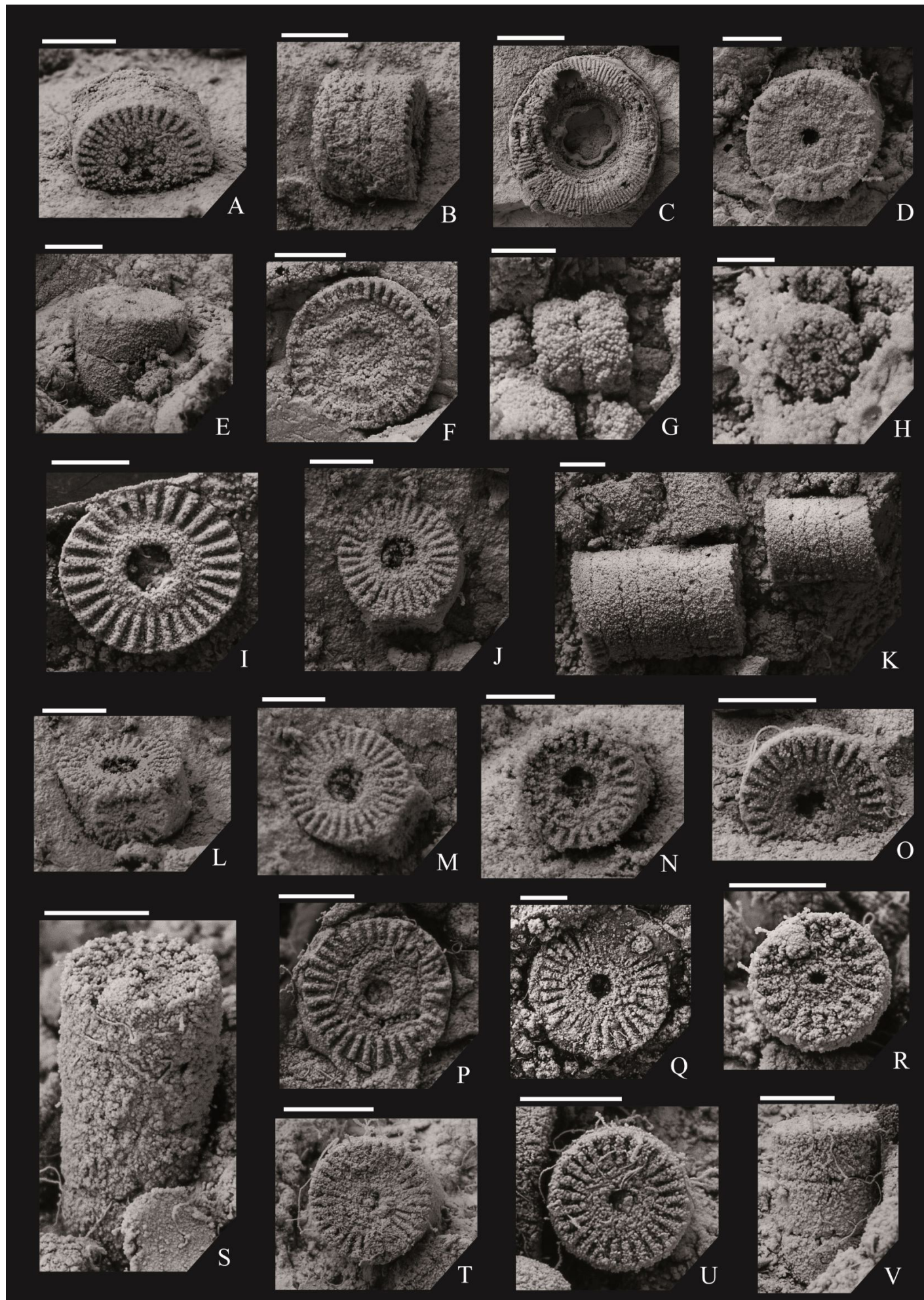

Figure 4 (A, B) Floricyclocion heteromorpha n. gen and n. sp., sample FCMP 1363. (C) Lamprosterigma erathense, sample FCMP 1364. (D-H) Preptopremnum cf. laeve, samples D, E) FCMP 1365; F) FCMP 1368; G, H) FCMP 1366. (I-N) Heterostelechus jeffordsi, samples I) FCMP 1369; J) FCMP 1370; K) FCMP 1373; L, M) FCMP 1370; N) FCMP 1372. (O, P) Heterostelechus cf. keithi, samples O) FCMP 1371; P) FCMP 1375. (Q-V) Cyclocaudiculus regularis, samples Q) FCMP 1377; R, S) FCMP 1376; T) FCMP 1378; U, V) FCMP 1379 . Scale bars = 2 mm, except $\mathrm{C}=5 \mathrm{~mm} ; \mathrm{G}, \mathrm{H}=1 \mathrm{~mm}$. 
Regarding columnar ossicles herein described and highlighting that all known taxa had been reported in Moscovian or Gzhelian (Middle-Late Pennsylvanian) localities of the United States, Mexico is the only country with previous Permian records of some taxa. Nonetheless, Russian work groups have also published descriptions of Permian material (Kotlyar et al., 2006; Biakov et al., 2016).

Except for the genus Pentagonopternix, they have not recorded any taxa from the late Paleozoic of Mexico or the south-central United States. With the current data, it can be stated that the columnar ossicles of Mexican localities, from Mississippian and Pennsylvanian ages, have high similarities with those recorded in localities of the Mid-Continent region (Villanueva-Olea et al., 2011; Villanueva-Olea and Sour-Tovar, 2015). Nonetheless, the lack of reports in the Permian of North America does not allow comparisons or correlations. Concerning the columnar ossicles described from the Grupera Formation, it can be noted that there are no coeval associations allowing comparative analysis outside Mexico, except Texas. However, considering the composition of the associated fauna, such as brachiopods or fusulinids, it can be hypothesized that common forms of crinoids might be found in Permian localities related to the Grandian Paleoprovince, located in Coahuila, Sonora and Chiapas from Mexico, New Mexico and Texas from the United States and Palmarito from Venezuela.

As mentioned above, the columnar ossicles of crinoids that are described in this work have already been referred to diverse localities of the Carboniferous or Permian of Mexico and all of them have records in localities of the Pennsylvanian of Texas. In Table 1, the occurrences and their bibliographic reference have been detailed. In this manner, it is observed that, some taxa have a very broad temporal distribution.

For example, Cyclocaudex typicus has a stratigraphic range from the Lower Mississippian to the Permian of Oaxaca. Cyclocaudex insaturatus was known from the Lower Mississippian of Oaxaca to the Pennsylvanian of Oaxaca and
Hidalgo, extending in the present work its temporal distribution to the lower Permian. Something similar is established for Lamprosterigma erathense, Heterostelechus keithi and Cyclocaudiculus regularis whose previous records were limited to Pennsylvanian localities. Cyclocaudex plenus, Preptopremnum leave and Heterostelechus jeffordsi have been previously reported in other Mexican localities of Permian age, including Baja California, Hidalgo and Guerrero. Hence, the record of all parataxa represents the first for the Permian (early Cisuralian) of Chiapas, Mexico, since the only previous reports of crinoids in the region were Cylindrocauliscus fiski? and Lamprosterigma mirificum, both from the Santa Rosa Formation (Carboniferous) of Chicomuselo (Buitrón-Sánchez, 1977). Because these parataxa have long temporal ranges, their biostratigraphic utility is still under discussion, yet, they are very useful to establish environmental features.

\section{Conclusions}

The report of eleven morphospecies of crinoid ossicles has allowed recognizing part of the marine invertebrates that inhabited the Chicomuselo region during the early Permian (AsselianSakmarian). The record of these taxa is the first made in Chiapas, Mexico, highlighting the occurrence of two new morphogenera: Floricyclocion and Cyclogrupera. These crinoids were deposited in a restricted marine environment of the inner ramp, characterized by well-oxygenated conditions, high productivity and good illumination. Previously, the taxa Cyclocaudiculus regularis, Heterostelechus keithi, Lamprosterigma erathense and Cyclocaudex insaturatus had only been recorded in different localities from the Pennsylvanian of North America but their occurrence in rocks from the Grupera Formation allows extending their stratigraphical range at least until the lower Cisuralian. The crinoid ossicles were deposited in a geographic region associated with the biotic Grandian Province of North America which groups different Permian localities of Mexico, Venezuela and the United States. 
Table 1. Occurrences and stratigraphic range of crinoid ossicles herein studied.

\begin{tabular}{|c|c|c|c|}
\hline Morphotype & Mississippian & Pennsylvanian & Permian \\
\hline $\begin{array}{l}\text { Pentagonopternix } \\
\text { Moore and Jeffords, } \\
1968\end{array}$ & & $\begin{array}{l}\text { - Sierra Agua Verde, Moscovian, } \\
\text { Sonora, Mexico (Buitrón-Sánchez et } \\
\text { al., 2015). } \\
\text { - Chaffin Limestone, Gzhelian, Texas, } \\
\text { USA (Moore and Jeffords, 1968). }\end{array}$ & $\begin{array}{l}\text { - Antiinskiy Horizon (Roadian- } \\
\text { Wordian), Transbaikal, Russia } \\
\text { (Kotlyar et al ., 2006). } \\
\text { - Imtachan Fm. (Lopingian), } \\
\text { Verkhoyansk, Rusia (Biakov et al ., } \\
\text { 2016). }\end{array}$ \\
\hline $\begin{array}{c}\text { Cyclocaudex typicus } \\
\text { Moore and Jeffords, } \\
1968\end{array}$ & $\begin{array}{l}\text { - Santiago Fm., Visean, } \\
\text { Oaxaca, Mexico } \\
\text { (Villanueva-Olea et al ., } \\
\text { 2011). }\end{array}$ & $\begin{array}{l}\text { - Ixtaltepec Fm., Bashkirian- } \\
\text { Moscovian, Oaxaca, Mexico } \\
\text { (Villanueva-Olea et al., 2011). } \\
\text { - Patlanoaya Fm., Gzhelian, Puebla, } \\
\text { Mexico (Villaseñor-Martínez et al ., } \\
\text { 1987; Esquivel-Macías, 1996). } \\
\text { - Thrifty Fm., Gzhelian, Texas, USA } \\
\text { (Moore and Jeffords, 1968). }\end{array}$ & $\begin{array}{l}\text { - La Cruz Fm., Wordian, Ihualtepec, } \\
\text { Oaxaca (Vachard et al ., 1997). }\end{array}$ \\
\hline $\begin{array}{c}\text { Cyclocaudex plenus } \\
\text { Moore and Jeffords, } \\
1968\end{array}$ & & $\begin{array}{l}\text { - Calnali, Hidalgo (Moreno-Cano and } \\
\text { Patiño-Ruiz, 1981). } \\
\text { - Graham and Thrifty fm., Gzhelian, } \\
\text { Texas, USA (Moore and Jeffords, } \\
\text { 1968). }\end{array}$ & $\begin{array}{l}\text { - Tuzancoa Fm., Sakmarian- } \\
\text { Artinskian, Pemuxco, Hidalgo } \\
\text { (Arellano-Gil et al ., 1998; Buitrón- } \\
\text { Sánchez et al ., 2017). }\end{array}$ \\
\hline $\begin{array}{c}\text { Cyclocaudex jucundus } \\
\text { Moore and Jeffords, } \\
1968\end{array}$ & & $\begin{array}{l}\text { - Del Monte Fm., Pennsylvanian, } \\
\text { Calnali, Hidalgo, Mexico (Buitrón- } \\
\text { Sánchez et al., 1987). } \\
\text { - Sierra Las Mesteñas, Pennsylvanian, } \\
\text { Sonora, Mexico (Villanueva-Olea et } \\
\text { al ., 2016). } \\
\text { - Cerros El Tule, Moscovian- } \\
\text { Kasimovian, Sonora, Mexico (Buitrón- } \\
\text { Sánchez et al ., 2012). } \\
\text { - Patlanoaya Fm, Gzhelian, Puebla, } \\
\text { Mexico (Velasco de León and Buitrón- } \\
\text { Sánchez, 1992). } \\
\text { - Thrifty Fm, Gzhelian, Texas, USA } \\
\text { (Moore and Jeffords, 1968). }\end{array}$ & $\begin{array}{l}\text { - Patlanoaya Fm, lower Permian, } \\
\text { Puebla, Mexico (Esquivel-Macías et } \\
\text { al ., 2000). } \\
\text { - Guacamaya Fm., Sakmarian- } \\
\text { Artinskian, Pemuxco, Hidalgo, Mexico } \\
\text { (Arellano-Gil et al., 1998). } \\
\text { - Tuzancoa Fm., Sakmarian- } \\
\text { Artinskian, Hidalgo, Mexico (Buitrón- } \\
\text { Sánchez et al., 1987). } \\
\text { - Cerros Los Monos, Wordian, Sonora, } \\
\text { Mexico (Buitrón-Sánchez et al., } \\
\text { 2007a). }\end{array}$ \\
\hline $\begin{array}{c}\text { Cyclocaudex } \\
\text { insaturatus Moore and } \\
\text { Jeffords, } 1968\end{array}$ & $\begin{array}{l}\text { - Santiago Fm., Visean, } \\
\text { Oaxaca, Mexico } \\
\text { (Villanueva-Olea et al ., } \\
\text { 2011). }\end{array}$ & $\begin{array}{l}\text { - Del Monte Fm., Pennsylvanian, } \\
\text { Calnali, Hidalgo, Mexico (Buitrón- } \\
\text { Sánchez et al., 1987). } \\
\text { - Ixtaltepec Fm., Bashkirian- } \\
\text { Moscovian, Oaxaca, Mexico (Buitrón- } \\
\text { Sánchez et al., 2000). } \\
\text { - Canabiss Fm., Moscovian, Kansas, } \\
\text { USA (Moore and Jeffords, 1968). }\end{array}$ & \\
\hline $\begin{array}{l}\text { Lamprosterigma } \\
\text { erathense Moore and } \\
\text { Jeffords, } 1968\end{array}$ & & $\begin{array}{l}\text { - Sierra Agua Verde, Atokan, Sonora, } \\
\text { Mexico (Buitrón-Sánchez et al., } \\
\text { 2007b). } \\
\text { - Mingus Shale, Moscovian, Texas, } \\
\text { USA (Moore and Jeffords, 1968). }\end{array}$ & \\
\hline
\end{tabular}


Table 1. (Continuation) Occurrences and stratigraphic range of crinoid ossicles herein studied.

\begin{tabular}{|c|c|c|c|}
\hline Morphotype & Mississippian & Pennsylvanian & Permian \\
\hline $\begin{array}{l}\text { Preptopremnum laeve } \\
\text { Moore and Jeffords, } 1968\end{array}$ & & $\begin{array}{l}\text { - Sierra Agua Verde, Pennsylvanian, } \\
\text { Sonora, Mexico (Buitrón-Sánchez et al., } \\
\text { 2005, 2007b, 2015). } \\
\text { - Cerros El Tule, Bashkirian, Sonora, } \\
\text { Mexico (Buitrón-Sánchez et al., 2012). } \\
\text { - Sierra Las Pintas, upper Pennsylvanian } \\
\text { - lower Permian Baja California (Navas- } \\
\text { Pareio et al.. 2018). } \\
\text { - Mingus Shale, Moscovian, Texas, } \\
\text { USA (Moore and Jeffords, 1968). }\end{array}$ & $\begin{array}{l}\text { - Sierra Las Pintas, upper Pennsylvanian } \\
\text { - lower Permian Baja California (Navas- } \\
\text { Parejo et al., 2018). }\end{array}$ \\
\hline $\begin{array}{l}\text { Heterostelechus jeffordsi } \\
\text { Miller, } 1968 \text { (in Moore } \\
\text { and Jeffords, 1968). }\end{array}$ & & $\begin{array}{l}\text { - Graham Fm., Gzhelian, Texas, USA } \\
\text { (Moore and Jeffords, 1968). }\end{array}$ & $\begin{array}{l}\text { - Olinalá/Los Arcos, Wordian- } \\
\text { Capitanian, Guerrero, Mexico (Flores de } \\
\text { Dios and Buitrón-Sánchez, 1982; } \\
\text { Esquivel-Macías et al.. 2004). }\end{array}$ \\
\hline $\begin{array}{l}\text { Heterostelechus keithi } \\
\text { Miller, } 1968 \text { (in Moore } \\
\text { and Jeffords, 1968). }\end{array}$ & & $\begin{array}{l}\text { - Del Monte Fm., Pennsylvanian, } \\
\text { Calnali, Hidalgo, Mexico (Buitrón- } \\
\text { Sánchez et al., 1987). } \\
\text { - Patlanoaya Fm, Gzhelian, Puebla, } \\
\text { Mexico (Velasco de León and Buitrón- } \\
\text { Sánchez, 1992). } \\
\text { - La Joya Fm., Pennsylvanian, Sonora, } \\
\text { Mexico (Buitrón-Sánchez et al., 2007b, } \\
\text { 2015). } \\
\text { - Cerros El Tule, Moscovian- } \\
\text { Kasimovian, Sonora, Mexico (Buitrón- } \\
\text { Sánchez et al., 2008). } \\
\text { - Graham Fm., Gzhelian, Texas, USA } \\
\text { (Moore and Jeffords, 1968). }\end{array}$ & \\
\hline $\begin{array}{l}\text { Cyclocaudiculus } \\
\text { regularis Moore and } \\
\text { Jeffords, } 1968\end{array}$ & & $\begin{array}{l}\text { - Sierra Las Mesteñas, Pennsylvanian, } \\
\text { Sonora, Mexico (Villanueva-Olea et al., } \\
\text { 2016). } \\
\text { - Thrifty Fm., Gzhelian, Texas, USA } \\
\text { (Moore and Jeffords, 1968). }\end{array}$ & \\
\hline
\end{tabular}

\section{Acknowledgements}

We appreciate all comments and suggestions by Gary D. Webster (Washington State University), Carolina Martín-Cao-Romero (Universidad Nacional Autónoma de México) and an anonymous referee, which have been very helpful in improving the manuscript. Likewise, we thank Torrey Nyborg for his language revisions, Erika Porras for her photographic work, Leonora Martin for the rubber casts and Daniel Navarro for his technical labor. This work was supported by the Dirección General de Asuntos del Personal Académico (DGAPA), Universidad Nacional Autónoma de México, through the project PAPIIT IA102618.

\section{References}

Arellano-Gil, J., Vachard, D., Yussim, S., Flores de Dios-González, A., 1998, Aspectos estratigráficos, estructurales y paleogeográficos del Pérmico inferior al Jurásico Inferior en Pemuxco, estado de Hidalgo, México: Revista Mexicana de Ciencias Geológicas, 15, 9-13.

Biakov, A.S., Zakharov, Y.D., Horacek, M., Richoz, S., Kutygin, R.V., Ivanov, Y.Y., Kolesov, E.V., Konstantinov, A.G., Tuchkova, M.I., Mikhalitsyna, T.I., 2016, New data on the structure and age of the terminal Permian strata in the South Verkhoyansk 
region (northeastern Asia): Russian Geology and Geophysics, 57(2), 282-293. https://doi. org/10.1016/j.rgg.2016.02.005

Buitrón-Sánchez, B.E., 1977, Invertebrados (Crinoidea y Bivalvia) del Pensilvánico de Chiapas: Revista del Instituto de Geología, $1,144-150$.

Buitrón-Sánchez, B.E., Patiño, J., Moreno, A., 1987, Crinoideos del Paleozoico tardío de Calnali, Hidalgo: Revista de la Sociedad Mexicana de Paleontología, 1, 125-136.

Buitrón-Sánchez, B.E., Flores de Dios-González, A., Vachard, D., 2000, Nuevos hallazgos de invertebrados paleozoicos (ScyphozoaConulata, Archaeogastropoda-Trochina y Echinodermata-Crinoidea) en la región de Nochixtlán-Ixtaltepec, Oaxaca: Geos, 20, 298.

Buitrón-Sánchez, B.E., Almazán-Vázquez, E., Vachard, D., Gómez-Espinosa, C., Mendoza-Madera, C., 2005, Crinoides pensilvánicos asociados a facies "arrecifales" de chaetetidos en Sierra Agua Verde, estado de Sonora, México: Geos, 25, 151.

Buitrón-Sánchez, B.E., Almazán-Vázquez, E., Vachard, D., 2007a, Middle Permian crinoids (Echinodermata, Crinoidea) from Cerros Los Monos, Caborca, Sonora, Mexico and paleogeographic considerations: Revista Mexicana de Ciencias Geológicas, 24, 344-353.

Buitrón-Sánchez, B.E., Gómez-Espinosa, G., Almazán-Vázquez, E., Vachard, D., 2007b, A late Atokan regional encrinite (early Moscovian, Middle Pennsylvanian) in the Sierra Agua Verde, Sonora state, NW Mexico. Paleozoic and Bioaccumulations. Climatic and Evolutionary Controls: Geological Society of London, Special Publications, 201-209. https://doi.org/10.1144/GSL. SP.2007.275.01.13

Buitrón-Sánchez, B.E., Gómez-Espinosa, C., Almazán-Vázquez, E., Vachard, D., Laguarda-Figueras, A., Solís-Marín, F.A., 2008, A review of the crinoid columnals (Echinodermata-Crinoidea) from the
Carboniferous of Mexico: Revista de Biología Tropical, 56, 1-12.

Buitrón-Sánchez, B.E., Vachard, D., AlmazánVázquez, E., Palafox, J.J., 2012, Una secuencia cratónica del Carbonífero al Pérmico inferior expuesta en los cerros El Tule, noreste de Sonora, México: Revista Mexicana de Ciencias Geológicas, 29, 39-62. Buitrón-Sánchez, B.E., Chacón-Wences, O., Vachard, D., Palafox, J.J., Jiménez-López, J.C., 2015, Pennsylvanian biota of the Sierra Agua Verde, Sonora, Mexico: biostratigraphic and paleogeographic considerations: Revista Mexicana de Biodiversidad, 86(2), 521-527. https://doi.org/10.1016/j.rmb.2015.04.006 Buitrón-Sánchez, B.E., López-Lara, O., Vachard, D., Hernández-Barroso, A.S., 2017, Algunos crinoides (Echinodermata-Crinoidea) del Pérmico de la región de Pemuxco, Hidalgo: Boletín de la Sociedad Geológica Mexicana, 69, 21-34. http://dx.doi.org/10.18268/ BSGM2017v69n1a2

Donovan, S.K., Doyle, E.N., 2019, Utility of crinoid columnals in palaeontology illustrated by a new species: Clare Shale Formation (Carboniferous), Doolin, County Clare, western Ireland: Proceedings of the Geologists' Association, 130(6), 696-700 https://doi. org/10.1016/j.pgeola.2019.02.004

Esquivel-Macías, C., 1996, Invertebrados del Paleozoico tardío de las regiones de Olinalá, Gro. y Patlanoaya, Pue.: Ciudad de México, Facultad de Ciencias, Universidad Nacional Autónoma de México, Master dissertation, $82 \mathrm{p}$.

Esquivel-Macías, C.,Ausich, W.I.,Buitrón-Sánchez, B.E., Flores de Dios, A., 2000, Pennsylvanian and Mississippian pluricolumnal assemblages (Class Crinoidea) from southern Mexico and a new occurrence of a column with a tetralobate lumen: Journal of Paleontology, 74(6), 1187-1190. https://doi.org/10.1017/ S0022336000017728

Esquivel-Macías, C., Solís-Marín, F., Buitrón Sánchez, B.E., 2004, Nuevos registros de placas columnares de crinoideos (Echinodermata, Crinoidea) del Paleozoico 
Superior de México, algunas implicaciones paleobiogeográficas y paleoambientales: Coloquios de Paleontología, 54, 15-23.

Fearnhead, F.E., Donovan, S.K., 2015, Fossil crinoids from the Valley of Rocks, Lynton, north Devon (Devonian): Proceedings of the Geologists' Association, 126, 582-588. https://doi.org/10.1016/j. pgeola.2015.08.006

Flores de Dios, A., Buitrón-Sánchez, B.E., 1982, Revisión y aportes a la estratigrafía de la Montaña de Guerrero: Universidad Autónoma de Guerrero, Serie Técnico Científica 12, 1-28.

Flügel, E., 2010, Microfacies of carbonate rocks. Analysis, interpretation and application: Springer-Verlag, 984p. https://doi. org/10.1007/978-3-642-03796-2

Gutiérrez-Gil, R., 1956, Bosquejo Geológico del estado de Chiapas, en MaldonadoKoerdell, M. (ed.), Geología del Mesozoico y estratigrafía pérmica del Estado de Chiapas: XX Congreso Geológico Internacional, Excursión C-15, 9-32.

Hernández-García， R., 1973， Paleogeografía del Paleozoico de Chiapas, México: Boletín de la Asociación Mexicana de Geólogos Petroleros, 25, 79-134.

Hess, H., Ausich, W.I., Brett, C.E., Simms, M.J., 2002, Fossil crinoids: Cambridge University Press, 290p. https://doi.org/10.1017/ CBO9780511626159

Jiménez-Hernández, A., Jaimez-Fuentes, A., Motolinía-García, O., Pinzón-Salazar, T., Membrillo-Ortega, H., 2005, Carta geológico-minera Huixtla Chiapas D15-2, 1:250000: Servicio Geológico Mexicano, 1 mapa.

Kotlyar, G.V., Popeko, L.I., Kurilenko, A.V., 2006, The Permian of the Transbaikal region, eastern Russia: Biostratigraphy, correlation and biogeography: Journal of Asian Earth Sciences, 26(3-4), 269-279. https://doi. org/10.1016/j.jseaes.2005.08.003

López-Ramos, E., 1979, Geología General y de México: Ciudad de México, Ediciones Escolares, Tomo II, 423p. y III, 454p.
Miller,J.S., 1821, A natural history of the Crinoidea or lily-shaped animals, with observations of the genera Asteria, Euryale, Comatula and Marsupites: Bristol, Bryan Press, 274p. https://doi.org/10.5962/bhl.title.1 1565

Moore, R.C., Jeffords, R.M., 1968, Classification and nomenclature of fossil crinoids based on studies of dissociated parts of their columns Paleontological Contributions, Echinodermata, Article 9: Kansas, The University of Kansas Publications, 114p.

Moreno-Cano, G.A., Patiño-Ruiz,J., 1981, Estudio paleozoico en la región de Calnali, Hidalgo (en la Sierra Madre Oriental): Ciudad de México, Escuela Superior de Ingeniería y Arquitectura, Instituto Politécnico Nacional, Bachelor thesis, 64p.

Müllerried, F.K.G., Miller, A.K., Furnish, W.M., 1941, The middle Permian of Chiapas, southernmost Mexico and its fauna: American Journal of Science, 239(6), 397406. https://doi.org/10.2475/ajs.239.6.397

Navas-Parejo, P., Lara-Peña, R.A., TorresMartínez, M.A., Martini, M., 2018, Biostratigraphy and petrography of upper Paleozoic rocks of Sierra Las Pintas, northern Baja California: Journal of South American Earth Sciences, 84, 160-171. https://doi. org/10.1016/j.jsames.2018.03.010

Shen, S.Z., Shi, G.R., 2004, Capitanian (Late Guadalupian, Permian) global brachiopod paleobiogeography and latitudinal diversity pattern: Palaeogeography, Palaeoclimatology, Palaeoecology, 208(3-4), 235-262. http:// doi.org/10.1016/j.palaeo.2004.03.009

Shen, S.Z., Zhang, H., Shi, G.R., Li, W.Z., Xie, J.F., Mu, L., Fan, J.X., 2013, Early Permian (Cisuralian) global brachiopod palaeobiogeography: Gondwana Research, 24(1), 104-124. https://doi.org/10.1016/j. gr.2012.05.017

Thomka, J.R., Mosher, D., Lewis, R.D., Pabian, R.K., 2012, The utility of isolated crinoid ossicles and fragmentary crinoid remains 
in taphonomic and paleoenvironmental analysis: an example from the upper Pennsylvanian of Oklahoma, United States: Palaios, 27(7), 465-480. https://doi. org/10.2110/palo.2011.p11-125r

Thompson, M.L., Miller, A.K., 1944, The Permian of southernmost Mexico and its fusulinid faunas: Journal of Paleontology, 18(6), 481-504.

Torres-Martínez, M.A., Sour-Tovar, F., Barragán, R., 2016, Permian (Leonardian) brachiopods from Paso Hondo Formation, Chiapas, southern Mexico. Paleobiogeographical implications: Journal of South American Earth Sciences, 71, 71-81. https://doi. org/10.1016/j.jsames.2016.06.012

Torres-Martínez, M.A., Barragán, R., SourTovar, F., González-Mora, S., 2017, Depositional paleoenvironments of the Lower Permian (upper Cisuralian) carbonate succession of Paso Hondo Formation in Chiapas State, southeastern Mexico: Journal of South American Earth Sciences, 79, 254-263. https://doi.org/10.1016/j. jsames.2017.08.018

Torres-Martínez, M.A., Heredia-Jiménez, D.P., Sour-Tovar, F., Buitrón-Sánchez, B.E., Barragán, R., 2019, Permian brachiopods from Chiapas, Mexico: new stratigraphical and paleobiogeographical insights: Paläontologische Zeitschrift, 93, 607-624. https://doi.org/10.1007/ s12542-018-0436-2

Vachard, D., Flores de Dios, A., Buitrón-Sánchez, B.E., 1997, Surune nouvelle localitéà fusulines du Wordien (Permien Supérieur) du Mexique: Conséquences paléogéographiques: Geobios, 30(3), 361-370. https://doi.org/10.1016/ S0016-6995(97)80196-9

Velasco de León, P., Buitrón-Sánchez, B.E., 1992, Algunos crinoideos
(Echinodermata-Crinoidea) del MisisípicoPensilvánico de San Salvador Patlanoaya, estado de Puebla: Revista de la Sociedad Mexicana de Paleontología, 5, 71-81.

Villanueva-Olea, R., Sour-Tovar, F., 2015, A new genus and four new species of cladid crinoids from the Carboniferous of Oaxaca state, Mexico: Journal of Systematic Palaeontology, 13(7), 527-542. https://doi.org/10.1080/14 772019.2014 .913719

Villanueva-Olea, R., Castillo-Espinoza, K.M., Sour-Tovar, F., Quiroz-Barroso, S.A., Buitrón-Sánchez, B.E., 2011, Placas columnares de crinoides del Carbonífero de la región de Santiago Ixtaltepec, Municipio de Nochixtlán, Oaxaca: consideraciones estratigráficas y paleobiogeográficas: Boletín de la Sociedad Geológica Mexicana, 63(3), 429-443. http://dx.doi.org/10.18268/ BSGM2011v63n3a5

Villanueva-Olea, R., Buitrón-Sánchez, B.E., Palafox-Reyes, J.J., Piña-Flores, S., 2016, Crinoides (Echinodermata: Crinoidea) del Pensilvánico de sierra Las Mesteñas, NE de Sonora, México: Revista Mexicana de Biodiversidad, 87(4), 1225-1234. https:// doi.org/10.1016/j.rmb.2016.10.014

Villaseñor-Martínez, A.B., Martínez-Cortés, A.M., Contreras y Montero, B., 1987, Bioestratigrafía del Paleozoico Superior de San Salvador Patlanoaya, Puebla, México: Revista de la Sociedad Mexicana de Paleontología, 1, 396-417.

Yancey, T.E., 1975, Permian marine biotic provinces in North America: Journal of Paleontology, 49, 758-766. 